\title{
Anti-Semitism and Anti-Semitic Organizations in Russia
}

\author{
Alexander Benifand
}

At Yeltsin's prereferendum meeting with representatives of Russian religious communities, Russia's Chief Rabbi Adolf Shaevich drew attention to increasingly "organized and open" antiSemitism in Russia. In reply, President Yeltsin claimed that there was no antiSemitism at any level of the Russian government. ${ }^{1}$ However, evidence seems to contradict him. There are numerous examples of anti-Semitism involving government officials at both the federal and local levels. There are different ways in which it is expressed: through the state's failure to curb the activities of anti-Semitic organizations and in some cases through financial support offered to antiSemitic organizations and publications. Furthermore, nationalist organizations are often headed by members of Parliament or other governmental officials.

According to Igor Gopp, chairperson of the American-Russian Bureau on Human Rights in St. Peterburg, Russia, anti-Western-and particularly antiAmerican-sentiments are openly and frequently expressed at public fora. Because Jews are associated with the proWestern orientation, they are viewed as "agents of foreign influence." 2

The Russian nationalist forces have started consolidating. Various conservative, nationalist and neo-fascist groups have formed an umbrella organization, the National Salvation Front. Three major blocs can be identified among them: the Russian Nationwide Union, the Russian People's Assembly and the Russian National Sobor. The Russian Nationwide Union, formed in December 1991 on the basis of the Russian parliamentary group, is an organization that defends Russia's territorial integrity. Its leader, Sergei Baburin, is a member of the Russian Federation's Supreme Soviet. The Russian People's Assembly, formed last

Alexander Benifand is a visiting research fellow at the Centre for Refugee Studies.
February at the Congress of Civic and Patriotic Forces, adheres to the position of "enlightened patriotism." Thisorganization used to receive support from VicePresident Alexander Rutskoi. The Russian National Sobor hadits Constituent Congress last February in Nizhni Novgorod. The cochairmen are a former major-general of the KGB, Alexander Sterligov, ${ }^{3}$ who is also the leader of the movement known as Officers for the Revival of Russia, and writer Valentin Rasputin. It has sixty-nine branches in all the republics of the former U.S.S.R. The first congress was attended by over a thousand delegates from 117 cities. It openly called for the formation of "red brigades" and the organization of a "movement of Russian national resistance." 4

These three organizations, headed by members of the Russian Parliament and other governmental organizations, represent the country's most powerful opposition force, which enjoys considerable support from the army, security organs, police and legal institutions. What makes it particularly dangerous is that national patriotic forces, including ultranationalist organizations, count on 70 percent support from among the Russian Army officers. And about twothirds of the officers would like to have a military-based regime introduced in Russia. ${ }^{5}$ The Russian military has warned of potential massive bloodshed. Senior officers said in a joint statement that "various political forces have started a struggle for influence over their army to reach their own goals." ${ }^{1}$ At a February 20-21, 1993 meeting of some serving and retired officers from the armed forces, the Security Ministry and the Internal Affairs Ministry, Stanislav Terekhov, the head of the militantly nationalist Officers' Union, claimed that the officers in the Russian General Staff and security organs supported their program. ${ }^{7}$ The coalition of the National Salvation Front is not monolithic. Yet at the presentstage, when its members are united by specific negative and destructive goals, they manage to put theirdisagreements aside. As former U.S. Secretary of State James A. Baker said with reference to Russian nationalists, whom heviews "as a greater danger than Soviet communism," "these extremists would draw their power not from what they stand for but from what they stand against: against the democrats who they argue are destroying Russia; against the capitalists who they argue are selling out Russia, and against the Westerners who they argue are doing both." 8

Nationalists count on violence and political instability, on the combination of legal and illegal, parliamentary and extraparliamentary forms of struggle. Any means, including the formation of armed forces, are considered acceptable to meet their final objective of taking power. ${ }^{9}$

Ultranationalist organizations that constitute the National Salvation Front publish more than 100 magazines and newspapers with a circulation of several million copies. They have a radio station and several TV programs.

The publication Russkoe Voskresenie (Russian Resurrection) has caused such a wave of indignation from the Russian public that its managing editor was detained. Yet shortly after he was released, he put forward his candidacy for city mayor. This was one rare attempt to deal with the spread of hate propaganda that produced no results. In other cases, the authorities do not do anything at all. Similar publications have wide circulation and are freely distributed at public places, but the authorities do not consider such activities illegal. In the words of one human rights activist, "this gives one an impression that the authorities are not protecting the 'right' but the rightwing." He goes on to say "We seem to have a democratic government. Have they moved a finger to stop fascist propaganda? No. The most odious incidents 
produced no reaction. Naturally, this makes fascists more blunt.... No one can understand why authorities are inactive at best, and at worst supportive of this propaganda inciting ethnic hatred. This is irresponsible and myopic." 10

Two or three years ago, only a few dozen people were associated with Pamyat and other similar organizations, but these organizations now have several million members. According to sociologist Galina Staravoitova, these sinister organizations are supported by 15 percent of the Russian population. The authorities are unable to ban or halt the development of these groups. Yeltsin's attempt to ban the National Salvation Front failed as the country's Constitutional Court claimed his move was unconstitutional. None of the appeals to the country's main prosecutor's office and to local branches to stop promoting racial hatred through nationalist newspapers brought results. This decision gave the green light to other similar organizations and their publications. ${ }^{11}$

Russian nationalists have developed their own military, which in some cases have acted as vigilante forces. ${ }^{12}$ Especially notorious are the Cossacks who enjoy substantial power in southern Russia but who have attempted to take control in Moscow and other parts of Russia. These military groups have ties to the army, national security agencies and criminal mafia, as well as large stores of weapons.

Though there are disagreements between some of these groups, the one thing they share is anti-Semitism. They persecute those who criticize them, as illustrated by the example of Pamyat's attack on the Moskovski Komsomolets newspaper. At a dedication ceremony of the U.S. HolocaustMemorial Museum, ${ }^{13}$ evenU.S. President Bill Clinton admitted that the Russian blackshirts represent a dangerous force.

Russian nationalism is backed up by the Russian Orthodox church. In his last interview, Father Alexander Men, a human rights activist, warned about the birth of Russian fascism, actively supported by many members of the clergy. He said, "There has been a reunification of Russian fascism with the Russian church. This is shameful for us believers...." Hegave this interview on September 5, 1990 and was murdered four days later. Father Alexander was the first victim of Russian fascism and this was not accidental: those who were behind it saw him as their major obstacle. ${ }^{14}$ There is a clear connection between the Russian Orthodox church and nationalism today. Clergymen frequently attend meetings of fascists, "blessing" them with their presence. The most extreme sections of national patriots firmly claim to be Christian. ${ }^{15}$

In various regions nationalist forces find support among local politicians. "Today you are the opposition press, but tomorrow you'll be at the helm of power," said Y. Nozhikov, head of the regional administration, at a meeting with the national patriotic organizations of Irkutsk. Last year the Irkutsk regional authorities allocated 150,000 rubles from their budget to support the Sibir magazine. At various periods, Sibir published anti-Semitic materials. The Irkutsk region administration became the first state structure in the history of Russia to shoulder the brunt of financing anti-Semitic newspapers and books. ${ }^{16}$ While anti-Semitism is no longer an official policy in Russia, the state maintains its anti-Semiticstand by its failure to protect ethnic minorities' human rights, including those of Jews.

\section{Notes}

1. Wendy Slater, "Yeltsin Meets Religious Leaders" Radio Free Europe no. 75 (April 21, 1993).

2. Igor Gopp, personal communication.

3. On March 20, 1993, the All Army Officers Assembly, attended by 255 delegates from nineteen Krais, met in Moscow. Segodnya reported that a number of conservative political leaders also took part, making a total of approximately 500 participants. Alexander Sterligov, a former KGB general who now heads the nationalist and procommunist Russian National Assembly, apparently gave a keynote speech in which he called upon the army to defend the constitution and to attempt to gain control over the Moscow mayoral election campaign. The assembly adopted an appeal to generals and officers in the army and the internal and security ministries urged them to disobey "anticonstitutional" orders from the president's office. (Stephen Foye, "Reports on Officers' Assembly," Radio Free Europe no. 57 (March 24, 1993).
4. Moscow News no. 29 (1992)

5. Major-General Vladimir Dudnik, "What to Expect From the Army at the Referendum," Moscow News (February 11, 1993).

6. "Boris Ducks Bullet," The Toronto Sun (March 26, 1993).

7. Radio Free Europe (February 22, 1993). According to Elliott and $O$ 'Brien, "Several months ago some people regarded Terekhov's organization, a motley group of disgruntled officers that can claim no more than a few hundred members, as a lunatic fringe. Now commanders worry that Terekhov's anti-reform activities could spread rapidly. Already he and other officers often march at the head of nationalist and communist demonstra. tions, emblazoned with medals in full military splendour." (Dorinda Elliott with Clinton O'Brien, "We Need Law and Order. The Army Wants Stability, But It Will Not Step In," Newsweek (April 5, 1993).

8. James A. Baker, "The Stakes For Them-and Us," Newsweek (April 5, 1993).

9. V. Ilyushenko, "Trichini," Literaturnaya Gazeta (April 14, 1993).

10. Ibid.

11. Lydmila Chyornaya, "Sud vdol' linii fronta" ("Trial Along the Front Line"), Literaturnaya Gazeta no. 7 (February 17, 1993).

12. The Russian National Legion (ultranationalistic military forces) is recruiting mortar men for the Dniester regions under its banners in central Moscow. The powers keep silent. All this puts Russia in a dubious situation. Now Russia can be blamed for creating conditions for recruitment of volunteers and thus adding fuel to the fire of ethnic conflicts. The 1907 Hague Convention bans using the territory of neutral states to recruit soldiers (volunteers or mercenaries) to fight in a country at war.

The Russian Foreign Ministry was first to react. In February it requested the Procurator's Office to take steps in connection with the public recruitment of soldiers, but the office is silent because there is no law banning recruitment in Russia.

About 30,000 volunteers and mercenaries participated in local wars on the territory of the former Soviet Union since 1990. About 2,000 people participated in the conflict on the territory of the former Yugoslavia.

In the near future, volunteers from Russia will still be confronting their compatriots on the front, as was sometimes the case in Abkhazia and Yugoslavia. (Vladimir Gubarev, "Wild Geese," The Jerusalem Post (January 25, 1993).

13. "Depravity Lives On, Clinton Warns," The Toronto Star (April 23, 1993).

14. Ilyushenko, "Trichini."

15. Ibid.

16. A. Krutov, “Local Executive Power Bodies Finance Russian Nationalists," Moscow News no. 10 (March 5, 1993). 